Article

\title{
Integrating Christian Spirituality at Work: Combining Top-Down and Bottom-Up Approaches
}

\author{
Peter McGhee
}

Management Department, Faculty of Business, Economics and Law, Auckland University of Technology, Auckland 1142, New Zealand; pmcghee@aut.ac.nz

Received: 10 June 2019; Accepted: 10 July 2019; Published: 16 July 2019

\begin{abstract}
This paper combines organizational and theological frameworks to address the integration of Christian spirituality at work (SAW). It begins with a brief explanation of SAW, followed by a more narrow description of Christian SAW. The paper then provides a snapshot of several integrative models from the SAW literature, after which it offers a new theological model of Christian SAW, noting that Christians want to contribute to God's new creation while worshipping Him through their work. Both this and the models from the SAW literature are considered to be 'top-down' approaches in that they provide guidance for managers on how to integrate employee spirituality. The next section then provides new 'bottom-up' qualitative research exploring the underlying conditions that working Christians believe are required for enhancing their spirituality at work. The paper concludes by bringing these two approaches together to produce a new theoretical contribution on how best to integrate Christian SAW, and to achieve the benefits of doing so for an organization.
\end{abstract}

Keywords: spirituality at work; Christianity; integration frameworks; theology of work; qualitative research

\section{Introduction}

For Pope John Paul II (Paul 1981), work is part of who we are and what we do. It touches all aspects of our lives, and is the primary means by which we improve those lives on earth. Consequently, he notes, that work is essential to the church's life and mission, and is "always relevant and constantly demands renewed attention and decisive witness" (p. 3). The Pope is not alone in this conviction. Robert Bellah (1985), the prominent American sociologist, argued in his well-known book, Habits of Heart, "Work that is intrinsically interesting and valuable is one of the central requirements for a revitalized social ecology" (p. 288) and what is needed is to improve society, "is a fundamental revaluation of what we understand work to be" (p. 289).

The Christian Bible clearly presents a view of human beings as Homo Faber. From the very beginning, God involves us in the work of creation, production and sustenance, and this continues through to the very end of creation. From the Garden of Eden (Gen. 1:27-28; 2:15; 9-20) to the New Jerusalem (Rev. 21:2), the Bible is full of verses proclaiming the need for, and the value of, work. There is also an underlying premise in scripture that work is a burden. The biblical narrative, while proclaiming its value, also stresses that more often than not, work is a curse rather than a blessing (Gen. 3:19).

Interestingly, the ideas of the two most influential secular thinkers on work reflects this conflict. Adam Smith, for example, advocated possessive self-interest as the "general principal which regulates the actions of every man" (cited in Volf 2001, p. 53). He wrote, "It is not from the benevolence of the butcher, the brewer, or the baker, that we expect our dinner, but from their regard to their own self-interest" (p. 54), and he acknowledged that this principle would inevitably mean, "The great body of the people must necessarily suffer alienation" (ibid.). For Smith, this was a price worth paying for 
a successful economy. Faced with this reality, Karl Marx rejected the notion that work was simply a means to material ends. For Marx, work was an instrument to humanize nature for individual self-actualization and societal development (Cosden 2005). Unfortunately, Marx's scientific materialism had little room for God. Interestingly, as Meeks (1989) observes, both systems argue for immutable laws rooted in the inevitability of history and nature, abstractly conceived, that colours their economic lens in utopian terms.

From a Christian perspective, both Smith and Marx get it half-right. As Pope Leo XIII's 1891 encyclical Rerum Novarum alludes to, each system, while promoting human self-actualization, actually ends up inhibiting human autonomy and dignity (Jensen 2006). Communism elevates the State, while capitalism elevates profit, both at the expense of the individual. Neither system has time for the God of scripture, nor have they yet provided their promised utopia. Remarkably however, the way most of us understand work today is still a product of these two systems (Casey 1995). Typically, work is organized in the interests of efficiency and profits, with workplaces, and the people within them, tools to achieve these ends. At the same time, work plays an enabling role in most of our lives, as it is the primary way we find fulfilment (Hunting and Conroy 2018).

Perhaps a developing awareness among Christians as to the dominance of the global economy, and its impact on people's working lives, underpins the recent flurry of publications concerning economics and work (in addition to the works already cited see, e.g., (Stevens 1999; Moe-Lobeda 2002; Larive 2004; Tanner 2005; Cavanaugh 2008; Keller 2012)). At the same time, a burgeoning literature has developed around the broader notion of spirituality at work (SAW). Several reasons have been provided by scholars for this interest including socio-demographic changes (Kale 2004; Marques 2010), shifts in collective worldviews (Biberman and Whitty 1997; Neal et al. 1999), and a growing wariness towards traditional institutions (Sweet 1999; Bell and Taylor 2003). Whatever the reason for this emergent interest, Miller and Ewest (2013) argue that SAW is more than just a fad. This paper hopes to contribute to this discourse by combining these two literatures to address the integration of Christian SAW, and to identify and discuss the benefits of this to organizations.

The paper begins with a brief explanation of SAW, followed by a more narrow description of Christian SAW. It then provides a snapshot of several integrative models from the SAW literature, with an emphasis on Miller and Ewest's (2015) approach for integrating religion and spirituality into an organization. After this, the paper provides a theological model of Christian SAW, noting that Christians want to contribute to God's new creation, while worshipping Him through their work. Both this and Miller and Ewest's work are considered to be 'top-down' approaches in that they provide guidance for managers on how to integrate employee SAW. The next section then provides new 'bottom-up' research exploring the underlying conditions that working Christians believe are required for enhancing their spirituality at work. The final part of the paper brings these two approaches together to produce a theoretical contribution on how best to integrate Christian SAW, and to discuss the benefits of doing so for an organization.

\section{What Is Spirituality at Work (SAW)?}

While popular in the management literature, defining SAW is challenging. There are multiple descriptions, with one author citing more than 70 (Karakas 2010b). Many of these are thick definitions that offer narrow interpretations of SAW, and in the process, leave out other vital aspects. A thin definition, on the other hand, is broad enough to incorporate many aspects and types of spiritualities. If we take this 'thin' approach, then SAW is about finding greater meaning in our work, cultivating an authentic holistic Self though our work, and engaging with our wider community by our work (Karakas 2010b; Benefiel et al. 2014; Houghton et al. 2016). A further idea prevalent in the literature is that everyone is spiritual (Downey 1997; Emmons 1999; Colwell et al. 2006) and therefore, when people come to work they bring that capacity with them (Sheep 2006; Berry 2013).

SAW is often conceptualized in the literature using three different levels: individual, collective and organizational (Sass 2000). At an individual level, SAW is the sum of beliefs and values a spiritual 
person brings to their work, and the effects of this on their organization (Kolodinsky et al. 2008). At this level, the focus is on how managers can enhance the spiritual capabilities of staff (Pfeffer 2003). At a collective level, SAW is comparable with organizational culture or identity. Giacalone and Jurkiewicz (2003), for instance, call it "the framework of organizational values evidenced in the culture that promotes employees' experience of transcendence through the process, facilitating their sense of being connected to others in a way that provides feelings of completeness and joy" (p. 13). Finally, for the organizational level, spirituality becomes consubstantial with the entity itself. SAW emerges as a complex system from the interactions occurring between individuals and organizational structures. This phenomenon is untraceable to any single person and has emergent properties that are holistically unique (Sass 2000). For the purposes of this paper, the phrase 'spirituality at work' (or SAW) means individuals enacting their spiritual values at an individual level, and the outcome of that enactment in their work-related context (collective level), unless otherwise stated.

This same literature also details the positive effects of embracing SAW. From increased commitment to the organization (Markow and Klenke 2005; Vandenberghe 2011; Bell-Ellis et al. 2015), to enhanced job satisfaction (Marschke et al. 2011; Tejeda 2015; Belwalkar et al. 2018), and improved citizenship behaviors (Kutcher et al. 2010; James et al. 2011; Pradhan and Jena 2015), SAW is increasingly seen as an idea whose time has come.

\section{What Is Christian SAW?}

Despite all this, Ewest (2018) writes "the way forward for people of faith to bring their whole selves, including their faith, into the workplace is opaque and resources to support them are scant" (p. 2). He goes onto detail that management scholars have little time for institutional religion, preferring the more ambiguous term spirituality. For instance, Mitroff (2003) argues that "organized religion has very little, if any role, to play in the workplace" (p. 378), a claim found throughout the literature (Bandsuch and Cavanagh 2005; Exline and Bright 2011; Carlson 2015). As Ewest (2018) notes, this usually occurs for two reasons: (1) religion is seen as divisive and pejorative, and (2) religion is too narrow a construct to attain the humanistic goal of a more humane workplace. Consequently, spirituality as a broader construct is of more interest to managers.

Historically, religion and spirituality were not widely differentiated (Schneiders 2003). Today, spirituality is typically segregated from religion. Whereas previously, religion included substantive and functional aspects while emphasizing personal religiousness, now spirituality is primarily substantive and emphasizes personal relationality. Overall, spirituality is viewed positively, while religion is viewed negatively (Zinnbauer et al. 1999). This discarding of religion for the broader term spirituality is interesting, and conceivably premature. Spirituality, after all is a central and essential part of most, if not all, religions (Schneiders 2003). Of course, there may be some who label themselves as spiritual only (Marler and Hadaway 2002). However, their spirituality did not evolve apart from cultural and social norms. While practices may differ in that such people do not hold to tradition-orientated religion, their sense of and search for an Ultimate Concern still exists, and this is a key aspect of any religion. Miller and Ewest (2018) argue that differentiating religion from spirituality “demonstrates a shallow understanding ... often setting up a false dichotomy between different modalities of belief systems and practices" (p. 4). Ultimately, both have similar ontological components. Interestingly, Boyd (1994) argues spirituality thrives in dialectical tension with religion, one calling for the other. For Schneiders (2003), they "constitute a single reality ... two partners in the search for God" (p. 165).

Miller (2007) uses 'faith at work', as opposed to 'spirituality at work' because it "recognizes the generalities and openness of spirituality and at the same time includes the particularities of the more codified and institutionalized nature of religion" (p. 18). From a Christian perspective, these are connected ideas. The New Testament, for instance, posits that a person of faith is ordered, led, and empowered by the third person of the Trinity, the Holy Spirit (see, e.g., 1 Cor. 2:6-15 and Rom. 8:9-11). This influence should result in certain actions. As scripture observes "What good is it, my brothers, if a man claims to have faith but has no deeds? Can such faith save him?" (James 2:14), as well as "In 
the same way, faith by itself, if it is not accompanied by action, is dead" (James 2:17). ${ }^{1}$ The actions James has in mind involve caring for "orphans and widows in their distress and to keep oneself from being polluted by the world" (1:27). Given this, we argue that an authentic (i.e., spiritual) Christian faith is one that images Jesus (2 Cor. 3:18; Col. 3:10) in terms of active love of others (especially the least well-off) and obedience to God (Luke 10:27; Jn. 14:15). Consequently, the notions of Christian faith and Christian spirituality at work are compatible since both involve a daily lived Christian praxis that images God back to Himself (McGhee and Habets 2018). This is opposed to other non-faith spiritualities (e.g., New Age), which may be conceived more loosely.

Simply put, Christian SAW is about having an active living faith in the workplace. However, if we take the thin definition provided earlier as a basis, then Christian SAW may involve finding purpose in our labors by directing them to God the Father, as the larger reality empowering our spirituality. Such a focus ensures there is no difference between the spiritual and the physical (i.e., labor) since both are an inseparable unity (Volf 2001). A Christian SAW would also require developing an authentic holistic self through our labors that images God's Son, Jesus Christ. By accepting Christ, our humanity is enhanced not diminished; our living, and our working, assume new purpose and relevance as we share in God's love and design for creation. Finally, a Christian SAW means laboring with the wider community (including the environment) by the Spirit to complete God's ultimate goal, a redeemed and renewed creation that expresses God back to himself (Staniloae 2000). Ferguson (2010) is also be helpful here. He offers the following directional metaphor of "reaching upward, opening inward, and expanding outward" (p. 16). In our work, we reach upward to be in harmony with God. As we strive upwards, we open ourselves to Jesus, which leads to a sense of wholeness through our work. This openness, in turn, ensures we expand outwards by the Spirit to connect with others, as we gain a sense of attachment to and integration with all life (Moltmann 1997).

\section{Integrating SAW from the Top-Down}

There is general agreement that people want to (and do) bring their spiritual worldviews and practices to their work context (Sheep 2006; Karakas 2010a; Houghton et al. 2016). Consequently, several authors have developed frameworks to help organizations integrate SAW. Among the first, was that of Mitroff and Denton (1999), whose research categorized organizations according to how they embraced spirituality. Their analysis concluded in advocating for a hybrid-type organization that incorporated the best of five identified approaches. Another early proponent in this area included Cash and Gray (2000), whose integration model is based on two categories: observance and manifestation. Observance involves "activities that include time away from work to celebrate holidays, to commemorate traditional events, or to attend Sabbath day services, as well as leaves of absence to attend religious or spiritual missions or retreats" (p. 128). Manifestation, on the other hand, "involves individuals' desire to express their religious experience at work and may result in requests to wear religious jewelry or dress or to discuss faith at work" (ibid.). In both instances, Cash \& Gray provide a framework that enables managers to assess religious institutional influence on employees' desire to be spiritual, and the subsequent impact of this desire on the organization.

Hicks (2003) (cited in Gotsis and Kortezi 2008) advocates for a 'respectful pluralism' approach to integration. Grounded on several arguments "not framed in the language of any particular religious tradition" (p. 164), Hicks' model involves "a series of basic assertions about the employee as a human person" (p. 166). These include people having an inherent dignity, and being respected accordingly, as well as all persons being treated equally, since all "possess equal dignity and thus deserve equal respect" (p. 167). It is on these basic assertions that any integration of spirituality into an organization must occur, not because its produces increased efficiency or improved financial returns. From Hicks'

1 All scripture verses are from the NASB (1995 update). 
perspective, spirituality is an inner human need, and therefore, must be treated as an end in itself (Gotsis and Kortezi 2008).

From this, Gotsis and Kortezi note that Hicks (2003) develops a guiding principle, the presumption of inclusion, which suggests that everyone should be permitted to practice their spirituality in their workplace. However, there are limitations to this. Such practice must meet sensible demands of the organization, and it cannot violate any other employee's rights to dignity and respect. Hicks also develops, what he calls, several limiting norms. The first of these is non-degradation. This inhibits employees engaging in any kind of degrading behavior towards others. Non-coercion, the second norm, limits individuals using official positions or power to force their spirituality on others. The third norm, non-establishment, ensures it is "morally unacceptable for an organization to endorse, or in any way promote, any particular religious or spiritual worldview over others, even if that worldview is deemed as generic or is intended to apply to all employees" (p. 174). Finally, and similar to this paper, Hicks claims the division between religion and spirituality is invalid. He believes that employees' religious and spiritual beliefs should be openly expressed and communicated in the workplace.

More recently, Pawar (2009) developed a wide-ranging framework of workplace spirituality that incorporates several methods of integration from current research. Pawar claims spirituality can be facilitated at work from an individual, group, organization, or leadership approach. The first of these involves cultivating spirituality within individual employees who then positively influence the organization. For example, Emmons (1999) notes that spiritual skills that enhance decision-making can be fostered via employee training and development programs. The second approach involves processes such as community building (see e.g., Mirvis 1997) that can "facilitate individuals' transcendence and access to spiritual knowledge for becoming their better selves" (p. 380). The third approach requires organizations to encourage individual experiences of SAW using more organic and flat structures, autonomous and participatory decision-making, self-managed teams, openness and transparency to spiritual beliefs and values, and collective recognition and reward systems (Pfeffer 2003). Pawar's (2009) final approach has leaders inducing change in aspects of the organization to generate employee experiences of workplace spirituality. For example, Fry's $(2003,2005)$ ideas about spiritual leadership posit that leaders empower followers through visioning that gives them a wider purpose for their work. For Fry, this means cultivating agreement between a given vision and firm values to achieve a good spiritual person and organization (SP-O) fit. This ultimately fosters increased commitment, improved performance and social responsibility. Pawar (2009) argues that when combined, these approaches produce a comprehensive integrated model reflective of existing research, with multiple focal points for researchers and practitioners.

Some scholars have shifted away from such generalized attempts to more industry-specific models. For instance, Lee et al. (2014) claim that service industries are uniquely affected by emotional labor, and that SAW can buffer the adverse consequences of this within an organization. Consequently, they offer a framework incorporating the influence of SAW on staff, clients, and the firm. They suggest

Spiritual values such as respect, humanism and integrity, when combined with an ethical climate, mediate the relationship between workplace spirituality and employee satisfaction and commitment, organizational performance and sustainability, and customer satisfaction and loyalty (p. 50).

For Lee at al., this happens because SAW creates an environment where staff are engaged in meaningful work, and are developing an authentic inner self, which ensures the negative effects of emotional labor occur less frequently. In addition to these, SAW also cultivates an organizational context where personal transcendence and connection with others is supported, and encourages spiritual P-O fit.

Focusing on the hospitality industry, Gatling's (2015) model begins with SAW empowering an individual's labor with personal meaning and purpose. This in turn, increases work energy and enjoyment. Next, SAW builds feelings of community which leads to improved connectedness between workers, empathy and support, and a shared vision. Finally, SAW generates alignment with broader 
organizational values. This encourages employees to connect with their organization's goals and mission. Combined, these generate several benefits including enhanced job satisfaction, an increased sense of commitment, and a reduced intention to quit. Not surprisingly, such outcomes are prevalent in the SAW literature.

The above models provide a snapshot of the SAW literature's efforts to integrate spirituality into organizations. While not exhaustive, these models do share some similar attributes. For instance, they all take a broad approach that could apply to a wide variety of spiritualities, industries, and organizations. Furthermore, they all articulate similar broad spiritual values, and they all contend that SAW will produce positive organizational outcomes, although this is not necessarily the goal. Such models are useful to a point but they often lack the faith specifics of religion (Miller and Ewest 2015). Stated another way, most are founded on an understanding of spirituality that is intrinsic and/or existentialist (Krishnakumar and Neck 2002). The first of these argues spirituality originates within us; it is part of our identity and outside religion's rules. Here, work is viewed as a mode for developing an authentic inner spiritual self. The existentialist view, on the other hand, interprets spirituality as a meaning-making construct; work is a vehicle that allows spiritual individuals to see their labors from a transcendent perspective. Neither view, however, is faith-specific. These differences led Krishnakumar and Neck (2002) to offer a third approach, that of the religious view. They describe this as being specific to a particular religion, with all its relevant beliefs, values and practices. For instance, Christians often view spirituality as a 'call to participate' with the work of the Triune God towards the redemption of creation (Volf 2001). Unfortunately, as Houghton et al. (2016) note, such religious perspectives are often marginalized in the SAW field.

In response to this lacuna, Miller and Ewest (2015) developed a faith-based integration model of SAW because "whether inadvertent or intentional, some models homogenize the variety of religious experiences, reduce them into categories of spirituality, or are dismissive of its presence within the workplace" (p. 314). Based on the earlier work of Miller (2007), they propose four approaches to faith in work contexts: faith-avoiding; faith-based; faith-safe; and faith-friendly. Noting that other integration models often include the first three of these approaches, Miller and Ewest (2015) contend that the 'faith friendly' model, and the overall holistic approach taken, are novel.

The faith-avoiding organization suppresses "personal or community expressions of faith, religion, and spirituality at work" (p. 316). These organizations see religion as problematic. Citing Follet (in Johnson 2007), Miller and Ewest claim this modality forces employees to compartmentalize. Unfortunately, when employees do this frequently, they can compromise their holistic self, which opens them up to mental health issues (Rozuel and Kakabadse 2010), as well as being more likely to carry out unethical behavior (Weaver 2006). Simultaneously, they are not as likely to produce the beneficial outcomes the SAW literature describes (Karakas 2010b). The faith-based organization, on the other hand, is the polar opposite of this; they tend to build the entire firm around one faith's orthodoxy (correct belief) and orthopraxy (correct behavior). Often these organizations have a founder or CEO whose strong faith influences the overall history and culture of the organization (Miller and Ewest 2015).

The faith-safe organization does not squash the expressions of faith, but at the same time, it does not encourage them either. Similar to the approach taken by Cash and Gray (2000), these organizations recognize employees' faith observance and manifestation requests, and accommodate these in line with legal requirements. If faith-avoiding means rejecting any forms of religious or spiritual expression outright, and faith-based means welcoming such expression with open arms as long as it limited to a singular faith, then faith-safe companies take a minimalist compromising approach. They do the bare minimum, which they are legally bound to do, and no more. Similar to the faith-avoiding organization, these firms are unlikely to get any real benefit from having spiritual employees (Miller and Ewest 2015).

Finally, the faith-friendly organization is a new way of appreciating the connection between faith and work. Unlike the faith-avoiding firm, this entity actively seeks to encourage and embrace all expressions of SAW equally. It goes "well beyond minimum legal requirements, and proactively welcomes and perceives employee and business benefits in appropriate manifestations of faith at 
work" (p. 319). These firms avoid the issues of compartmentalization mentioned earlier. They do this because they recognize all people bring their spirituality to work, and they want to live in ways that allow them to incorporate their private and public lives (Sheep 2006; Lynn et al. 2011). They also know that such integration generates positive health outcomes for employees (Zellars and Perrewe 2003; Arnetz et al. 2013), and positive work outcomes for the organization (Walker 2013; Belwalkar et al. 2018).

\section{Integrating Christian SAW from the Top-Down}

While an improvement on previous attempts at integration, Miller and Ewest's (2015) model is still a top-down, organization-centric approach, and is broad in its application of religion. It does not answer the question: "How might a Christian integrate their faith at work such that they remain true to its orthodoxy and orthopraxy?" (Krishnakumar and Neck 2002). Historically, such interaction has been understood in three ways (Jensen 2006). One stream of thinking viewed work ascetically. It was an antidote to laziness, and a means of creating disciples, all the while generating wealth for the common good. Work had both a restraining and a productive function-"rescuing the soul from idleness, and whetting the taste for spiritual things" (p. 32). Unfortunately, such thinking tended to elevate the spiritual over the physical, and ultimately, created a dichotomy between clerical work (which was viewed as superior) and the ordinary efforts of laypersons (Volf 2001).

Another stream of thought saw work as a calling. In response to Catholic views that only clerical work was spiritual, and an aspiring bourgeoisie with economic interests, the Protestant reformers argued all Christians had a spiritual and a worldly call (Volf 2001). Martin Luther, perhaps the best-known proponent of this view, believed every person in every job is a priest, fulfilling his or her work as a God-given duty (Zapf and Seele 2018). For Luther, work belongs to humans "as the birds to flying" (p. 105), meaning that as part of the natural order, all work is equally socially and theologically relevant. When conceptualized as a calling or a vocation, work becomes a divine assignment powered by God's grace; it does not matter what a person does, as long as they do it for God. Later reformers extended this idea, arguing that calling was discerned not on the basis of station but rather on the basis of gifts and abilities (Dik et al. 2012). Both Luther and Calvin, as well as the later Puritans, all believed that "diligent service within the work role glorifies God and also advances the well-being of society" (p. 115).

Unfortunately, some of the early reformers' ideas about work have produced some unjust outcomes. For instance, they have been used to justify socio-economic hierarchies that exploit and alienate workers (Volf 2001). As the result of these, another stream of thought developed which viewed work as a form of salvation (Jensen 2006). Enlightenment thinkers such as G.W.F Hegel, after noting that human work denigrated to slavery under capitalism, sought to transform the nature of work such that it led to self-actualization. For Hegel, the Absolute Spirit "let loose in the world will not rest in alienation ... Spirit seeks expression, in part, through the work of our hands and minds" (pp. 37-38). Using images from Exodus, Hegel posits that properly oriented work makes human beings free. Ironically, it was Hegel's spiritual view of work that laid the foundation for Karl Marx's atheist ideas. For Marx, work was ontological in that humanity invents itself and the world through its labor (Cosden 2005). However, this happens only when the workers collectively own the means of production; until then, industrial capitalism will continue to exploit and alienate the proletariat.

Twentieth-century Christian thinkers also differ on the integration of faith and work. Karl Barth (1961), perhaps the foremost modern theologian, saw work as an economic necessity, and the Bible as supporting this understanding. He stated, "There is no option but to work. Hence one of the favorite insights of Protestant ethics, namely the importance of work to human personality and as a cultural enterprise is very much in the background, if not completely invisible" (p. 472). For Barth, earthly work is of secondary importance for Christians, whose main role is to be an active disciple of Christ. Jacques Ellul (1976) goes further, arguing that work has no absolute value. It is a necessary evil that has 
No ultimate or transcendent value before God ... It is simply that which makes our survival possible and keeps us in being ... Work is an everyday affair. It is banal. It is done without hope. It is neither a value nor is it creative ... when satisfaction is given ... when human work produces joy ... we have to realise this is an exceptional event, a grace, a gift of God for which we must give thanks (pp. 505-6).

More recently, theologians such as Douglas Meeks (1989), Paul Marshall (1980), Miroslav Volf (2001) and David Jensen (2006) have taken a more positive view, claiming that Christian work by definition participates in God's plan for creation, and has eternal worth. Along similar lines, McGhee and Habets (2018) developed an integrative model of Christian spirituality and work using the ideas of T.F. Torrance (see Figure 1).

According to Torrance (cited in Flett 2005), human beings are "defined by, and sustained within our relations to God, the created order and fellow human beings" (p. 163). Consequently, differentiating between our faith as spiritual and our work as physical is unfounded. Furthermore, because we are constituted by God for all we are, and can become, "we are dependent upon a continuing relationship and proper orientation towards that same God" (p. 169). However, this is only possible through our relationship with Jesus Christ, whom Torrance (1992) calls the "Personalizing Person" and the "Humanizing Human" (pp. 67, 69), and by the work of the Spirit who sustains this relationship. Hence, the work of Christ and the Spirit does not replace our humanity, rather it redeems it such that we become more human not less, and our work takes on new meaning as we participate in God's divine love and plan for creation. This ontological change also restores our relationship with God, and with each other, and we are now able to image God back to Himself through our decisions and actions. For Torrance (1965), this is the true telos (or end) of being human. Flett (2005) notes that this image is dynamic in that it is personal, spiritual and social; without the social context (e.g., work), humanity could not "fulfil its calling and vocation as such a being" (p. 171).

Noting the limitations of calling as it is historically understood, the authors use an idea taken from Torrance (1980) to conceptualize the Image of God (Imago Dei) in a work context, as that of human beings as Priests of Creation and Mediators of Order. As priests, humanity's calling is to "assist the creation as whole to realize and evidence its rational order and beauty and thus express God" (Habets 2009). It is not as Luther might have us believe, remaining in one's demeaning monotonous job, all the while viewing it as a calling from God. As mediators, Torrance (1996) argues that humanity "is the one constituent of the created universe through whom its rational structure and astonishing beauty may be brought to word in praise of the Creator" (p. 213). How redeemed humanity orders its environment becomes a form of embodied worship, a living and concrete witness of God. Thus, Christians bring forth order and beauty that would not have been possible otherwise. This is their true calling, to co-create and act as stewards of God's creation. For Torrance (1982), this occurs primarily through the natural sciences but both Flett (2005) and Habets (2009) argue that this is too narrow a conception. If we take this idea into a social context (e.g., work), then our daily labors also enact our priesthood and mediation.

What might this look like in practice? As embodied beings, all work is spiritual unless it violates God's law (e.g., loan sharking in Deut 24:17-18; Ps 112:5; Mal. 3:5; Matt. 21:12). At the same time, we are personal beings, our work is unique to us, and as such, it takes on new importance because whatever we do, it conforms us to the image of God, who is Jesus Christ (2 Cor 3:18). For instance, we image God in our labors when we treat others as ends and not means (e.g., opposing exploitative labor practices), and when we steward God's creation as opposed to diminishing it (e.g., reducing the causes of climate change). Finally, as relational beings, work becomes an important social context by which to enact this image. The picture that best captures this is the notion of human beings as co-creators and co-redeemers with God through our work. 


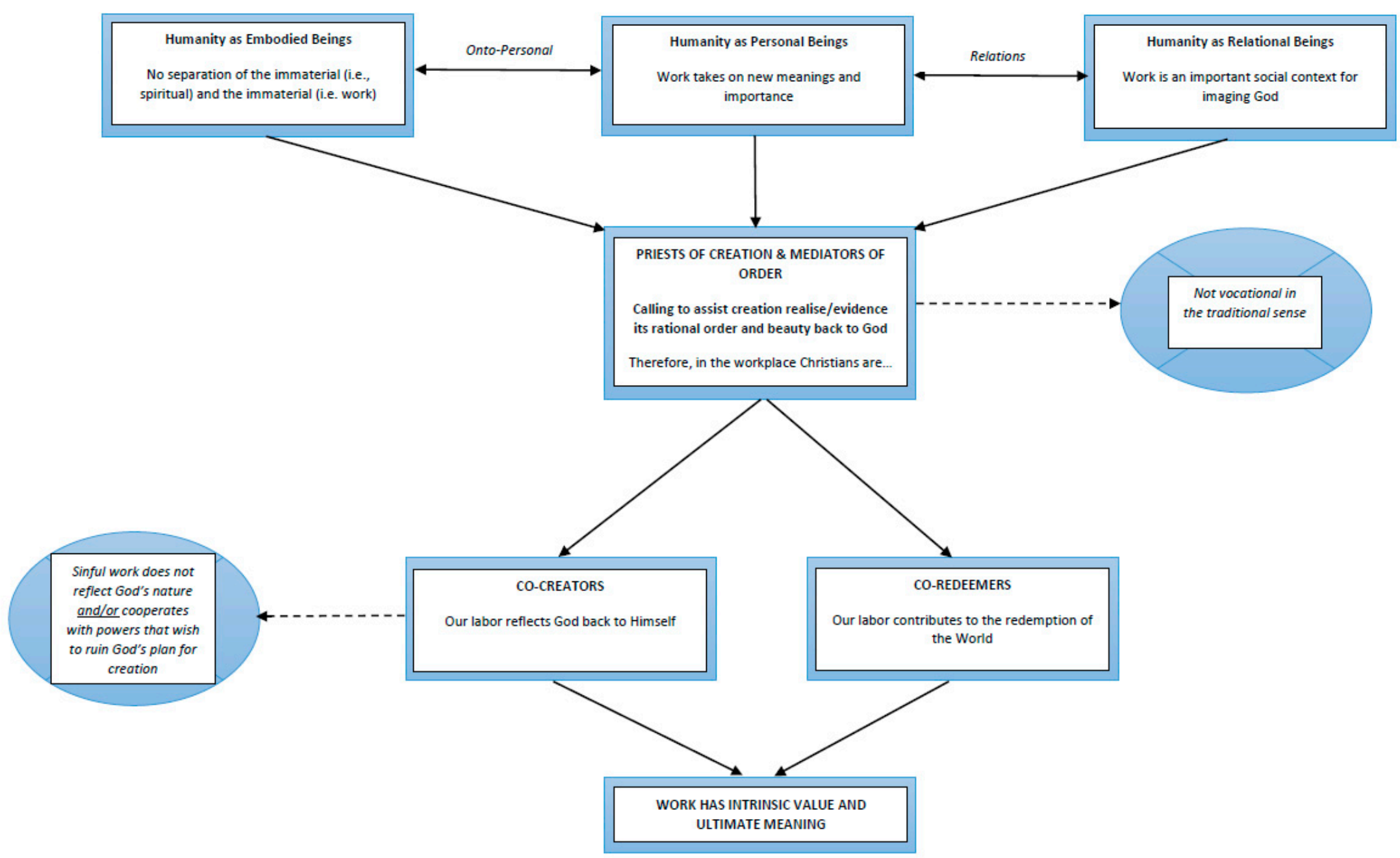

Figure 1. Humanity at Work (Adapted from McGhee and Habets 2018, p. 85). 
As co-creators, a Christian's labor participates in God's new creation, and involves doing work that reflects God's image in us back to Himself. Dorothy Sayers (Sayers [1949] 2011), the influential Christian author and playwright, wrote that:

[Work is] a way of life in which the nature of man finds its proper exercise and delight and so fulfils itself to the glory of God. That it should, in fact, be thought of as a creative activity undertaken for the love of the work itself; and that man, made in God's image, should make things, as God makes them, for the sake of doing well a thing that is well worth doing (p. 15).

In other words, work has value in itself; it is a necessary aspect of becoming fully human. As Sayers writes, work is where we find "spiritual, mental, and bodily satisfaction, and is the medium in which we offer ourselves to God" (p. 18).

As co-redeemers, Flett (2005) contends that humans are "peculiarly constituted and uniquely called to improvise with God as 'scientist', 'midwife', 'priest', and 'instrument' in order to draw the created order toward its telos" (p. 182). Telling the story of how God works in His creation involves the embodiment and expression of God's purpose for it. This story, however, cannot be told apart from the formation of specific communities and their concrete action in the world. Workplaces are one such community, and it is through these Sayers (Sayers [1949] 2011) writes, that we "serve God, and the work itself must be accepted and respected as the medium of divine creation" (p. 21). Consequently, work that is exploitative, wearisome, or destructive (including towards the environment) is prohibited since it does not reflect God's nature and often cooperates with powers that wish to ruin God's telos for creation. Since we labor for God, "Christian work is good work well done" (p. 23). As Christians, if we focus on the demands of our good work, then this is a guarantee that divine ends will also be met and met well.

When work is conceived in these terms, it becomes vocational in a holistic theological sense. Since our labors participate via the Holy Spirit in God's eschatological transformation of the present, any view of work that is selfish, dehumanizing, and focused on material goals at the expense of spiritual ends is problematic. When viewed through the lens of co-creators and co-redeemers, our work takes on intrinsic value and ultimate meaning as it looks forward to God's new heavens and new earth (Flett 2005). After developing this theological framework, McGhee and Habets' (2018) applied it deductively to data collected from 21 Christians in a previous study (see McGhee 2015). As a result of this analysis, they found that Christians frequently acted as "embodied witnesses to the glory and eternal purposes of God" (Flett 2005, p. 176), and in doing so, brought another dimension to their organizations. This dimension fostered service to humanity's real needs, developed a corporate distinctiveness that focused on character and virtues, and enhanced decision-making to transcend individual and organizational self-interest.

While theologically useful, this framework has limitations, some of which also manifest in the SAW frameworks discussed earlier. First, it is conceptual. It applies abstract ideas and theories taken from the theological literature. Second, it is a macro perspective. It views work as a broad theological construct; it is not specific to any particular industry or firm. Finally, it implies a top-down approach. In real life, interpreting work and organizations using this framework may have little meaning or value to those who are experiencing the reality of trying to integrate their SAW. As part of that same original study by McGhee (2015), participants also discussed how their organizations might enhance their SAW. To date, these findings have not been analysed or reported in any detail. This paper now turns its attention to these in an attempt to better understand how Christians can live out their SAW, and what organizations can do to assist this from the 'bottom-up'.

\section{Integrating Christian SAW from the Bottom-Up}

To understand how Christian SAW can be better integrated, one can investigate Christian individuals with real-life work experiences. Such individuals should embody a lived spirituality (Fornaciari and Dean 2009), putting their beliefs and values into practice daily in their organizational 
context. The literature also states that spirituality develops over time, and that younger people may experience spirituality differently, as well as having less work experience (Lips-Wiersma 2002; Wink and Dillion 2002; Colwell et al. 2006). Consequently, older and spiritually mature individuals are likely to provide more useful insights.

With these criteria in mind, the interview transcripts of 21 Christians from McGhee's (2015) original research, who were over the age of 30 and who scored 130 or higher on Howden's (1992) Spirituality Assessment Scale (SAS) ${ }^{2}$ were selected for analysis. All participants were in full time employment in the services industry. The semi-structured interviews occurred in their place of work or a public place, and lasted between $60-90$ minutes. The sample consisted of $11(52 \%)$ males and $10(48 \%)$ females. More than half the sample had been in the workforce for $15+$ years, with over $80 \%$ having spent at least 10 years working. Nearly all the participants had a university education $(90 \%)$, with eight (38\%) having a postgraduate qualification. As part of their interviews, participants answered questions about whether, and how, their organization integrates (or fails to integrate) their SAW (see Table 1). While collected as part of McGhee's (2015) original study, to date, this data has not been reported and/or discussed in relation to Christian SAW in any meaningful way. ${ }^{3}$

Table 1. Interview questions about integrating Christian SAW from McGhee (2015, p. 263).

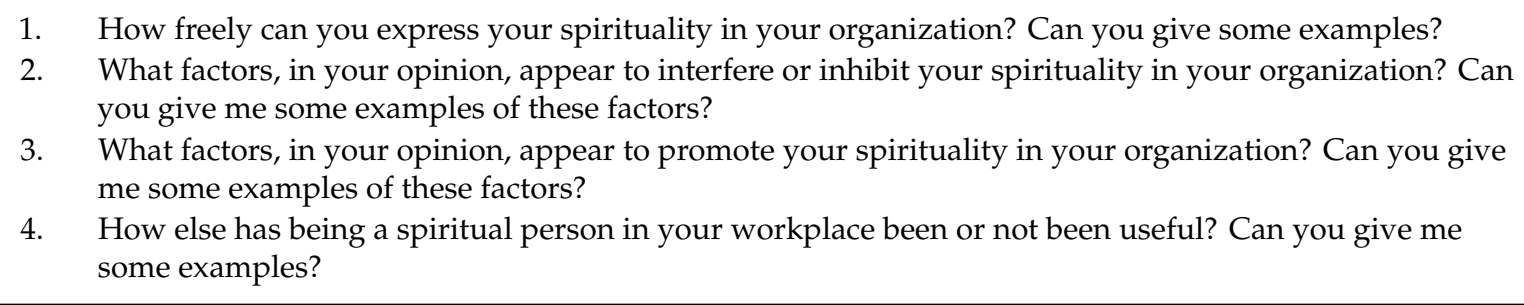

Interview data was input into NVivo, and Braun and Clarke's (2006) six-step thematic analysis ${ }^{4}$ was used to examine this. This "works both to reflect reality and to unpick or unravel the surface of reality" (p. 81), and is commonly used in SAW research (see e.g., Sass 2000; Issa and Pick 2011; Karakas and Sarigollu 2015). From this thematic analysis, four global themes (or causes/conditions) emerged: Open Culture to Spirituality, Provide More Autonomy, Aim for Higher Goods, and Supportive Spiritual Leadership. These conditions were mentioned by all 21 participants either directly or indirectly. Each is described below with several evidential data extracts in support of the theme.

\subsection{Open Culture to Spirituality}

Organizations that allow spiritual people "to speak openly and express their inner feelings, values and spirituality, regardless of fear, alienation or exclusion" (Karakas 2010b, p. 101) in a manner that gives them constructive feedback (Cavanagh 1999; Cash and Gray 2000; Krishnakumar and Neck 2002)

2 Howden's (1992) Spirituality Assessment Scale (SAS) is an older scale that measures a broad understanding of spirituality that applies to both Theistic and non-Theistic spirituality. It is a Likert scale of 28 statements which can be scored Strongly Disagree (1) to Strongly Agree (6). Total spirituality scores can range from 28 (very weak spirituality) to 168 (a very strong spirituality). Individuals that scored over 130 for this study had a strong spirituality. The SAS used in this study had a reliable alpha of 0.80 .

3 All subjects gave their informed consent for inclusion before they participated in the study. The study was conducted in accordance with the Declaration of Helsinki, and the protocol was approved by the University of Auckland Human Participants Ethics committee (2010/561).

4 This involved (1) being familiar with the data; (2) creating initial codes; (3) identifying organizing themes, which are Attride-Stirling (2001) state are "a cluster of signification that summarise the principle assumptions of a group of basic themes" (p. 389); (4) identifying global themes, which are "super-ordinate themes that encompass the principle metaphors in the data as a whole" ibid.; (5) checking themes worked in relation to transcripts (vertical) and entire data set (horizontal), and generating clear definitions for each theme; and (6) finding compelling data extract examples for each global theme. 
may encourage SAW. The extracts in Table 2 demonstrate that in permitting individuals to exercise their spiritual values, they engaged with the organization more and this often led to better outcomes.

Table 2. Extracts in support of Condition 1-Open Culture to Spirituality.

You have these decisions, I mean things come up, and I will talk quite openly about, I will even put it in spiritual terms ... I've had some really difficult staff management challenges and I think being a spiritual person has given me just that source or God to go to ... I think in decision-making, it's going back to my spiritual or biblical values and that's what ultimately improves my decisions, the organization is quite open to that-Community Sports Manager We have rules of course about assessment or curriculum, when there is a degree of flexibility there's often a choice about, you know, do I give an extension here, do I not? Is this the right way? You kind of play all those things off; it [spirituality] becomes part of the decision. My School is happy for me to bring that dimension in-Teacher I guess career planning, you see opportunities at work where you can actually make a difference, and you can have a position that enhances others. I am an energetic person so I want to change what I'm doing often so I then seek other opportunities. My spirituality is part of that process. The department doesn't ask me to ignore that, they want to include it as part of any job choice-Nurse

That [being allowed to exercise spiritual values] makes all the difference in the world about, whether you go, when you go to work, whether you enjoy your day or not. I know other companies that have engineers on staff, they're not engineering companies, but the work culture is toxic. And, I think it's probably because they're stuck in this compartmentalization where everybody is criticizing everybody else's projects to build up their own power and security-Director

Well beyond the mere practice of law it's [spirituality] been helpful in sharing with staff through various situations they've personally been in because they know what I believe and I've been able to convey that to them which I think has been helpful to them in a lot of situations-Lawyer

\subsection{Provide More Autonomy}

Spirituality is a holistic phenomenon. As such, it resists the control, formalization and reductionism of bureaucratic structures so common in modern organizations. Such structures by nature focus on external goods and short-term goals and this often drives decision-making (Giacalone 2004; Zsolnai 2004; Lips-Wiersma and Nilakant 2008). Therefore, structures, polices and processes that provide more autonomy, self-management, and distributed decision-making may enhance SAW (Pfeffer 2003; Pawar 2009). Participants' extracts in Table 3 support this claim. Note that the last two extracts take the reverse perspective, demonstrating what happens when organizations do not encourage autonomy.

Table 3. Extracts in support of Condition 2-Provide More Autonomy.

The fact that you're, underneath it all, irrespective of who employs us and what our role is, we are actually all people too and we all belong to an [organizational] community. And often a lot of my decisions are based on spirituality and that sense of, a sense of self and others and what can we do for others-Communications Consultant There is nothing in the organization that inhibits spirituality that can't be dealt with if you are in the right frame of mind. It's not an organization that will outright stop it. It allows you freedom of speech; it allows you to express a spiritual opinion. In fact, it's better now than it was when it was owned by the previous owners-Sales Engineer The organization that I work for offers a really positive environment to be spiritual. And that probably comes down to the individuals I work with in that they're not particularly micro-managers. They like a bit of diversity on the team and they look at a multi-person approach to dealing with a situation. So they're not so quick to say "we don't want that option included in the care of that child"—Student Liaison Manager

In this system it seems quite difficult to discuss things at higher levels. It's quite a hierarchical organization. And you get the impression, "how dare you question these things" ... I mean in some ways it's a real barrier. And that's the stuff that presses my buttons because there isn't clear processes for addressing issues. I'm pretty tired of it all really. It's a big bureaucracy and things do work slowly, but it actually inhibits spirituality-Psychologist I guess the organizational structure here is that we have a lot of prima donna managers ... and so we've got a lot of them around the place and they're on a pedestal, you don't argue with certain people ... I think if I spent more time away from work, and reflected more on my spirituality, I'd probably come back and be like, I really don't feel good about this. You can be so busy, and the organization can demand so much, that you shut the spiritual part out-Project Manager 


\subsection{Aim for Higher Goods}

For spiritual persons, cultivating an inner flourishing life, having strong community interconnectedness, and striving for transcendent purposes, as well as the more mundane (e.g., the bottom line) is important. What role can organizations play in helping such persons achieve these? One thing they could do is have goals and strategies that aim at similar ends (as well as the bottom line). If this the norm, then spiritual praxis may be enhanced as individuals see a good fit between what the firm is doing and what they believe (Gotsis and Kortezi 2008; Moore 2008). Again, several extracts are provided in Table 4 as proof of this theme.

Table 4. Extracts in support of Condition 3-Aiming for Higher Goods.

\footnotetext{
I think it [spirituality] gives a different worldview to what's going on, to why you're doing things. I'm not simply there [at work] to get an income. I'm not there just to take, that's not my driving motivation. That to me is the real tangible like reality of spirituality personally because it's like I am not hung up about the income and the material-Control Systems Engineer

You're not just there [at work] to make money; this is what people don't get. I have to make a profit because that is what I employed to do but there is a difference between making a profit and profiteering ... My spirituality as a whole has made me become a better person but it is probably the most evident through my job in a way because that is where I rely on it more-Sales Engineer

My spiritual values speak for themselves ... My belief system gives me a worldview too. It's not just about me and my family, or my job, it's about a bigger picture ... And looking at it through the lens of, you know, what does that look like for the wider community? And how's that gonna impact society? Certainly, these things have to matter for any organization I work for-Student Liaison Manager

And I think in decision making, it's going back to my spiritual or biblical values and that's what, I mean ultimately guides my decisions [at work]. I mean for me, I couldn't work for an organization that was ripping people off, I couldn't work for an organization that went against my beliefs. You know if I worked for Telecom but they were doing stuff over here for funding brothels or ... I just couldn't work for them. I'd rather cut lawns [laughs]. Just wouldn't go ... wouldn't work for me-Community Sport Manager

Are those goals the organization has reasonable? Are they consistent with my [spiritual] beliefs?" Ultimately, in the end I came to the conclusion that if they actually weren't and that's why I left the company-Product Manager
}

\subsection{Supportive Spiritual Leadership}

For Fry (2003), spiritual leadership involves "values, attitudes, and behaviors that are necessary to motivate intrinsically one self and others so that they have a sense of spiritual survival through calling and membership" (p. 711). Congruent with these insights, participants in this study identified leadership as an important requirement for providing the visions and goals that gave employees a sense of meaning beyond instrumental ends. Spiritual leaders act in altruistic ways, care for others and aspire to community. They set the tone of the organization and in doing so, strengthen the prospect that employees will fit their spiritual values with their work context. Table 5 provide extracts in support of this theme. 
Table 5. Extracts in support of Condition 4-Supportive Spiritual Leadership.

It's vital in a leadership position that you set the spiritual tone and actually be an enabler, because, within a
spiritual culture, you can ask the best of people, you can encourage doing good-Director
Yeah, I think it [spirituality] does [improve culture] because in my role as the leader of this group of businesses I
guess I have an influence over how people behave morally and so on ... in a sense I have the opportunity to set
some boundaries [with my spiritual values] in those areas which in my view has to be positive overall for the
business not just the bottom line-Director
I think that [being a spiritual leader] would be a daily conflict because I guess the organizational structure and
management style in general, what the companies wanting to achieve overall I think, there would be some
conflicts. But without such people, it's going to be harder to get other spiritual people's buy in-Project Manager
Actually, I think it's [spirituality] the salt of the earth, and I think it changes the whole tone of the work culture if
spiritual people are leading. Because, they're focused on an ethical result, rather than on individual technical
achievement-Director
When you're a leader in an organization-your spirituality helps influence the people who work for you and they
understand where your basis of decision making comes from ... Recently, I wrote down my top four values, and
then I asked the rest of the team to write down what they thought my values were. Because I guess what they
wanted to see was, is what I value, does that actually come through? Does anyone else know or see that? And on
the whole it was a really high hit rate which was great for me. Several of them, talked about my faith as something
important, and something that made it easier for them exercise their own spiritual values-Community Sport
Manager

\section{What Does This Mean for Christian SAW?}

McGhee and Habets (2018) contend that Christians want to work in ways that image God's creative activity (Priests of Creation) and bring glory to Him (Mediators of Order). As Flett (2005) notes, "the church's mission is not spiritual in any narrow sense, but cultural, since it is her function to stand as the embodied witness of the glory and eternal purpose of God" (p. 176). When Christians image God at work they are worship made flesh; an incarnate and tangible sign of God in the world. This stands in contrast to the dominant economic ideology, which Volf (2001) states, "has little to do with either worship of God or with God's demands on human life; it has to do with worship of self and human demands on the self" (p. 129).

Because of their desire to image God, Christian's bring another dimension to their work; a dimension that serves humanity's real needs, helps develop an organizational culture that emphasizes moral character, and that encourages decision-making that overrides personal and corporate self-interests. For instance, McGhee and Habets (2018) found that Christians helped set the ethical tone at work and contributed to sustainable ethical change. The literature supports this, affirming that the intrinsically religious (i.e., those for whom religion is more than affiliation) are more ethical in business (Kennedy and Lawton 1998; Singhapakdi et al. 2000; Longnecker et al. 2004; Emerson and McKinney 2010; Comer and Vega 2011), and take a stronger stance on corporate social responsibility (Angelidis and Ibrahim 2004; Jamali and Sdiani 2013; Mazereeuw-van der Duijn Schouten et al. 2014). Such behavior contradicts the tendency in many organizations to suppress moral choices, to value means more than ends, and to ignore social and environmental costs (Moore 2008).

McGhee and Habets (2018) also found that Christians viewed work as more than a job. Work was a calling, but not to some menial occupation or to some fixed position in society, but rather "to liberate creation from its bondage to decay", and in doing so, Christians bring their work-life into "conformity with the way it has been ordered by Father and redeemed by the Son" (Flett 2005, pp. 176, 178). In other words, participants believed their work collaborated with God to fulfil his plans for the new creation, which made their work both 'good' and 'meaningful' (Volf 2001). Because of this, participants were able to reject co-optation of their spirituality for instrumental ends, as well as enacting their spiritual values in the face of counterforces which encourage dehumanizing work practices (Giacalone 2004; Ghoshal 2005). As a result, participants felt a deep sense of wholeness. This makes sense if you think of humans as musical instruments, which are in tune with God when their work is reflective of Him. The flipside were those participants who failed in their priestly duties, who were out of tune, and were 
unsuccessful in imaging God to creation as worship. Such persons reported feelings of discontent, anxiety and meaninglessness depending on the extent of their inauthenticity.

Again, the literature supports this finding. The resent study by Meskelis and Whittington (2018) on work as worship found that people bring meaning to their work through a sense of calling that leads them to it as a 'living sacrifice' and a 'reasonable act of worship' (Rom. 12:1-2). Duffy et al. (2010) concur, noting that for Christians, work provides meaning as well as a way of demonstrating their faith. Concurrently, those that fail to view work this way are more apt to experience conflicts of will and emotional distress (Johnson 2007). Unfortunately, as Rozuel and Kakabadse (2010) note, such individuals may also "yield more easily to the pressure of social conformity, relinquishing their personal responsibility by claiming to be just an agent in the system" (p. 426).

Milliman et al. (2017) posit "that people tend to prefer and thrive in environments which are compatible with their own skills, interests, values, and other individual characteristics (p. 1). Moreover, both individuals and organizations can intentionally manage this fit to suit their needs (Barrick et al. 2013; Yu 2013). Scholars have shown that this perceived Person-Organization (P-O) fit influences employee's work attitudes positively, as well as increasing organizational citizenship behaviors (Verquer et al. 2003). Given this, and the substantial benefits of Christian SAW, how might the 'bottom-up' themes found in this study (Open Culture to Spirituality, Provide More Autonomy, Supportive Spiritual Leadership, and Aim for Higher Goods) combine with Miller and Ewest's (2015) faith-based model to better integrate Christian SAW. Table 6 below summarises the fit between what Christians in this study desired and the capability of each organization type in Miller and Ewest's model.

Table 6. Application of Miller and Ewest's (2015) framework to global themes.

\begin{tabular}{ccccc}
\hline & Faith-Avoiding & Faith-Safe & Faith-Based & Faith-Friendly \\
\hline Open Culture & No & Some & Yes/No & Yes \\
More Autonomy & No & Some & Yes/No & Yes \\
Supportive & No & No & Yes/No & Yes \\
Leadership & No & No & Yes/No & Yes \\
Higher Goods & & & &
\end{tabular}

The faith-avoiding organization will not have a culture open to expressions of Christian SAW. Indeed, such organizations are likely to view Christian spirituality as being private to an individual, and of limited or no consequence to operations (Van Buren 1995). According to Sheep (2006), they may also be concerned with Christian religious discourse stirring up controversy by breaching topics considered off-limits, or of individuals "proselytizing vulnerable workers to imposed, hegemonic belief systems" (p. 359). While such entities may well have increased democracy and worker autonomy, these do not encourage spiritual expression. They may inadvertently allow some Christian influence, but it is not their intent. As Alexis (2015) states, such firms "deliberately adopt policies to ensure workplace secularity to honor the convictions of the irreligious" (p. 1).

Leaders in these types of organizations may well be transformational (Bass 1990), but they are unlikely to set a spiritual tone. They are unlikely to promote Fry's (2003) "values, attitudes, and behaviors that are necessary to motivate intrinsically one self and others so that they have a sense of spiritual survival through calling and membership" (p. 711). Because such faith-avoiding entities provide no support for SAW, they would be a weak $\mathrm{P}-\mathrm{O}$ fit for Christians who wish to be co-creators and co-redeemers with God through their work. According to Verquer et al. (2003), these organizations will reap limited, if any, benefits from such persons since they will feel disengaged when personal and organizational values collide. Having such a weak perceived $\mathrm{P}-\mathrm{O}$ fit means individuals process behavioral expectations less thoughtfully and effectively, which can inhibit employees from reaching their full potential.

The faith-safe organization will have a culture open to the expressions of Christian SAW but with a caveat. They allow a minimalist expression of spirituality within the limits as required by law 
(Lund Dean et al. 2014). In New Zealand, this includes Bill of Rights Act 1990 and the Human Rights Act 1993. The Bill of Rights sets out the fundamental freedoms of anyone subject to New Zealand law, including the freedom to manifest religious belief and practice in public, while the Human Rights Act 1993 protects against discrimination for exercising one's religion in public. In addition to these, the New Zealand Government has signed a number of International Labor Organization (ILO) covenants of which one, the Discrimination (Employment and Occupation) Convention 1983, also protects religious expression at work. What this means in practice is that these organizations are 'spirituality friendly' and respectful, but they are not necessarily welcoming of Christian SAW, nor will they necessarily view expressions of this as a beneficial resource (Cash and Gray 2000). In terms of autonomy, the same applies. Faith-safe organizations create just enough structures, processes, and policies to accommodate minimal faith expression. While they allow individuals some freedom, they do not encourage the use of Christian spiritual resources (e.g., prayer and meditation) in their daily organizational life (Emmons 2000).

Similar to faith-avoiding organizations, leadership in faith-safe entities may be either good or bad, but it is unlikely to be overtly spiritual. Since these organizations tend to take a 'hands-off' approach to SAW, their leaders don't typically create congruence between spiritual visions (if they have one) and spiritual values across all levels of the organization (Fry 2003). Given they are representatives of organizational authority, they cannot (or will not) do more than the bare minimum in this space (Miller and Ewest 2015). Again, the P-O fit for Christians will be weak if they understand work as a priestly mediatorial act. While these organizations may reap some benefits of Christian SAW, any value is likely to be accidental and minimal.

The faith-based organization is open to SAW and usually has structures, processes and policies that freely cultivate employee spiritual expression, as well as spiritual leadership that supports this. For example, several large firms have corporate chaplains to enhance employee's work experience and well-being (Miller et al. 2017). Some have prayer rooms or include moments of meditative silence at meetings (McCarty 2007), while others encourage the use of spiritual resources in decision-making thereby, reaping the benefits of individual and group expressions of spirituality (Bandsuch and Cavanagh 2005). The Chief Executive Officer and/or senior management team are transparent about their faith, and they embed their spiritual values in the culture and operations of these entities (Delbecq 1999; Konz and Ryan 2000; Fernando 2007).

The acceptance of SAW in these types of organizations is religion-specific. If the entity is overtly and clearly grounded in the Christian tradition, then individuals wishing to practice Christian spirituality should be able to do so without hindrance and the P-O fit will be good (Miller and Ewest 2015). If, however, the organization's core religious value system is not Christian, then at best, integration occurs as if the organization was either faith-safe or faith-avoiding. At worst, Christians might feel excluded, causing them to hide their spirituality and, therefore, negate any benefits to the organization. Moreover, if the organization is grounded in another faith tradition, then subtle discrimination may also be a problem. For example, McCarty (2007) argues that managers who promote spiritual activity are inclined to support participants over non-participants. Consequently, the $\mathrm{P}-\mathrm{O}$ fit for Christians seeking to exercise their spirituality in faith-based organizations is dependent on which religion is being promoted.

Miller and Ewest's (2015) faith-friendly organizations have cultures that are fully open to all forms of SAW, including Christian. They also establish structures, processes, and policies that enable the free expression of SAW equally (Ashforth and Pratt 2003). Put another way, these entities support members (including Christians), via organizational resources instead of by management control, to determine the desired type or degree of spirituality (Sheep 2006). By incorporating Christian spirituality into such aspects as job design, job crafting and participatory decision-making, these organizations can enhance engagement. These include, for example, involving employees in job tasks that allow them to put their spirituality into practice (Pratt and Ashforth 2003; Karakas 2011), or designing job roles that incorporate spiritual goals (Emmons 1999) and that help employees improve feelings about their ability 
to achieve these ends (Snyder et al. 2011). Additionally, these faith-friendly organizations frequently have overt leadership that models spiritual efficacy (Bandura 2003), while mentoring employees' inner life and spiritual practices to enhance well-being, and ultimately improve the triple-bottom line (Fry and Nisiewicz 2013). Research has shown that such mentoring is a salient influence on Christian work-spirituality integration (Lynn et al. 2011).

The $\mathrm{P}-\mathrm{O}$ fit for Christians in these organizations is strong. Since these firms encourage SAW, Christians have the freedom to participate through their labors in God's plan for creation, as well being inspired to consider their work as worship back to God (McGhee and Habets 2018). Since this creates work that has ultimate meaning and value for Christians, the organization is likely to reap several benefits including enhanced job satisfaction, organizational commitment, in-role performance, and organization citizenship behaviors (Meskelis and Whittington 2018).

Conspicuous by its absence in the discussion above is the fourth condition that participants identified as necessary for integrating Christian SAW. It is conceivable that all four organizations identified in Miller and Ewest's (2015) model could aim for eudaimonic goods such as facilitating the common good, and contributing to human flourishing (as well as hedonic goods, e.g., profit, market share, and increased efficiency). Prima facie, all four organization types might be a strong P-O fit for Christians based on this condition. However, for both the Faith-Avoiding and Faith-Safe organizations, aiming for eudaimonic ends is unlikely to involve overt spiritual aspects, or be sourced in spiritual motivations (Guillén et al. 2015). The other two organizational types aim at these 'goods of excellence' (Arjoon et al. 2015) because spiritual beliefs and values are embedded in their organizational identity and culture, and in the practices of their leadership and employees (Delbecq 1999; Danyluk 2002; Fry and Nisiewicz 2013; Dyck 2017; Driscoll et al. 2019).

Ideas like the common good and human flourishing may have different meanings in secular and religious discourse (Tongo 2016). From a religious perspective, Arjoon et al. (2015) contends that the common good must be "directed to the service of people in their totality, taking into account their material needs and the requirements of their intellectual, moral, spiritual, and religious lives" (p. 150). To meet this goal, business must be "anchored in a theory of transcendence (promoting self-giving and a spirit of service that goes beyond professional obligations and legal requirements-looking to eternity)" (p. 153). Faith-Based and Faith-Friendly organizations recognize that the market cannot function fully without reference to humanity's spiritual well-being. Consequently, Arjoon notes, such entities might promote a version of the common good that includes both physical and spiritual aspects.

Fostering the common good encourages human flourishing (eudaimonia). From a Christian perspective, this involves pursuing happiness, not via individualistic hedonic means, but by striving to connect with God, and one's wider community. Doing this motivates individuals to regulate their conduct in accordance with their spiritual ideals, and to alter or reject actions that conflict with these ideals. Moreover, the nature of this process ensures these actions are habitually practiced and, thus, constantly actioned in their organizations (Gull and Doh 2004). This ensures a strong P-O fit, as well as generating potential benefits for the firm.

\section{Conclusions}

From early ascetic and vocational approaches to more contemporary theories, Christians have endeavored across the centuries to integrate their spirituality into their work. Recently, using the work of T.F. Torrance, McGhee and Habets (2018) developed a model that argued a Christian's work contributes to God's final telos for creation, while simultaneously imaging God back to Himself as a form of worship. When this occurs, work has ultimate meaning and value. Interestingly, secular interest in SAW has also grown over the last three decades, and with that growth, comes an increased need to integrate spirituality into modern organizations. Indeed, several authors offer frameworks as guidance for this. One of these is Miller and Ewest's (2015) framework that categorizes entities as faith-avoiding, faith-safe, faith-based and faith-friendly. 
Realizing that many attempts to integrate Christian SAW (both theological and practical) suffer from similar concerns, this paper provided a summary discussion about research which asked working believers what they thought organizations could do better to integrate their spirituality. Retroductive analysis of their responses determined four conditions participants believed would improve SAW: (1) having an organizational culture open to spirituality (2) having structures, processes and policies that encourage the free expression of spirituality, (3) having spiritual leadership in the organization that supports SAW; and (4) aiming at higher goods or ends. These were then matched to Miller and Ewest's four organizational types to understand which generated the best perceived $\mathrm{P}-\mathrm{O}$ fit. Of the four types, faith-based and faith-friendly are reasoned to be strongest for integrating Christian SAW. These organizations are most likely to have the culture, structures, leadership, and purpose required for Christians to feel like they are contributing not only to the firm and its stakeholders, but also to God's transformatio mundi via their work.

The $\mathrm{P}-\mathrm{O}$ fit literature suggests that congruence between persons and the organization is vital to maintain adaptable, motivated, and dedicated employees (Verquer et al. 2003). From a Christian perspective, there is a greater need to understand the causes and methods by which spiritual values and the organizational context match, how this match be enhanced, and how it influences work-related behaviors. At the same time, managers also need to understand what types of organizations best integrate Christian SAW, and what the benefits of integration are. This article endeavors to meet these needs by combining 'top-down' (theological and organizational) and 'bottom-up' (research from working Christians) approaches. Given concerns about the lack of employee engagement (Bakker et al. 2011), and a growing spiritual consciousness (Sheep 2006), this paper addresses crucial issues facing organizations in relationship to the well-being of its employees and the wider society.

Funding: This research received no external funding.

Conflicts of Interest: The author declares no conflict of interest.

\section{References}

Alexis, Gwendolyn. 2015. Not Christian, but nonetheless qualified: The secular workplace-Whose hardship? Journal of Religion \& Business Ethics 3: 1-24.

Angelidis, John, and Nabil Ibrahim. 2004. An exploratory study of the impact of degree of religiousness upon an individual's corporate social responsiveness orientation. Journal of Business Ethics 51: 119-28. [CrossRef]

Arjoon, Surendra, Alvaro Turriago-Hoyos, and Ulf Thoene. 2015. Virtuousness and the common good as a conceptual framework for harmonizing the goals of the individual, organizations, and the economy. Journal of Business Ethics 147: 143-63. [CrossRef]

Arnetz, Bengt, Matthew Ventimiglia, Pamela Beech, Valerie DeMarinis, Johan Lökk, and Judith E. Arnetz. 2013. Spiritual values and practices in the workplace and employee stress and mental well-being. Journal of Management, Spirituality \& Religion 10: 271-81.

Ashforth, Blake E., and Michael G. Pratt. 2003. Institutionalized spirituality: An oxymoron? In Handbook of Workplace Spirituality \& Organizational Performance. Edited by Robert A. Giacalone and Carole L. Jurkiewicz. Armonk: M. E. Sharpe, pp. 93-107.

Attride-Stirling, Jennifer. 2001. Thematic networks: An analytical tool for qualitative research. Qualitative Research 1: 385-405. [CrossRef]

Bakker, Arnold B., Simon L. Albrecht, and Michael P. Leiter. 2011. Key questions regarding work engagement. European Journal of Work and Organizational Psychology 20: 4-28. [CrossRef]

Bandsuch, Mark R., and Gerald F. Cavanagh. 2005. Integrating spirituality into the workplace: Theory and practice. Journal of Management, Spirituality \& Religion 2: 221-54.

Bandura, Alfred. 2003. Commentary: "On the psychosocial impact and mechanisms of spiritual modeling". International Journal for the Psychology of Religion 13: 167-73. [CrossRef]

Barrick, Murray R., Michael K. Mount, and Ning Li. 2013. The theory of purposeful work behavior: The role of personality, higher-order goals, and job characteristics. Academy of Management Review 38: 132-53. [CrossRef] 
Barth, Karl. 1961. The doctrine of creation. In Church Dogmatics, Vol. 3, Part 4. Edited by Gerald. W. Bromiley and Thomas. F. Torrance. Edinburgh: T\&T Clark.

Bass, Bernard M. 1990. From transactional to transformational leadership: Learning to share the vision. Organizational Dymanics 18: 19-31. [CrossRef]

Bell, Emma, and Scott Taylor. 2003. The elevation of work: Pastoral power and the New Age work ethic. Organization 10: 329-49. [CrossRef]

Bellah, Robert. 1985. Habits of Heart: Individualism and Commitment in American Life. Berkley: University of California Press.

Bell-Ellis, Rhonda S., Linda Jones, Molly Longstreth, and Judy Neal. 2015. Spirit at work in faculty and staff organizational commitment. Journal of Management, Spirituality \& Religion 12: 156-77.

Belwalkar, Shibani, Veena Vohra, and Ashish Pandey. 2018. The relationship between workplace spirituality, job satisfaction and organizational citizenship behaviors-An empirical study. Social Responsibility Journal 14: 410-30. [CrossRef]

Benefiel, Margaret, Loius W. Fry, and David Geigle. 2014. Spirituality \& religion in the workplace: History, theory, and research. Psychology of Religion \& Spirituality 6: 175-87.

Berry, Priscilla. 2013. Fostering Spirituality in the Workplace: A Leader's Guide to Sustainability. New York: Business Expert Press.

Biberman, Jerry, and Michael Whitty. 1997. A postmodern spiritual future for work. Journal of Organizational Change Management 10: 130-38. [CrossRef]

Boyd, Tom W. 1994. Is spirituality possible without religion? A query for the postmodern era. In Divine Representations: Postmodernism E Spirituality. Edited by Ann W. Astell. Mahwah: Paulist Press, pp. 83-101.

Braun, Virginia, and Victoria Clarke. 2006. Using thematic analysis in psychology. Qualitative Research in Psychology 3: 77-101. [CrossRef]

Carlson, Julie. 2015. Bringing faith to work. Baylor Business Review 33: 26-27.

Casey, Catherine. 1995. Work, Self and Society. London: Routledge.

Cash, Karen C., and George R. Gray. 2000. A framework for accommodating religion and spirituality in the workplace. Academy of Management Executive 14: 124-34. [CrossRef]

Cavanagh, Gerald F. 1999. Spirituality for managers: Context and critique. Journal of Organizational Change Management 12: 186-96. [CrossRef]

Cavanaugh, William T. 2008. Being Consumed: Economics \& Christian Desire. Grand Rapids: W.B. Eerdmans.

Colwell, Ronald K., Chris Kiesling, Marilyn J. Montgomery, and Gwendolyn T. Sorell. 2006. Identity \& spirituality: A psychosocial exploration of the sense of spiritual self. Developmental Psychology 42: 1269-77.

Comer, Debra R., and Gina Vega. 2011. The relationship between the personal ethical threshold and workplace spirituality. Journal of Management, Spirituality and Religion 8: 23-40. [CrossRef]

Cosden, Darrell. 2005. Theology of Work: Work $\mathcal{E}$ the New Creation. Eugene: Wipf \& Stock.

Danyluk, Vera. 2002. Managing a public organization: A projection of one's ethical and spiritual values. In Ethics and Spirituality at Work. Edited by T. C. Pauchant. Westport: Quorum Books.

Delbecq, Andre L. 1999. Christian spirituality and contemporary business leadership. Journal of Organizational Change Management 12: 345-49. [CrossRef]

Dik, Bryan J., Ryan D. Duffy, and Andrew P. Tix. 2012. Religion, spirituality, and a sense of calling in the workplace. In Psychology of Religion and Workplace Spirituality. Edited by Peter. C. Hill and Bryan. J. Dik. Charlotte: Information Age Publishing, pp. 113-33.

Downey, Michael. 1997. Understanding Christian Spirituality. Mahwah: Paulist Press.

Driscoll, Cathy, Elizabeth M. McIsaac, and Elden Wiebe. 2019. The material nature of spirituality in the small business workplace: From transcendent ethical values to immanent ethical actions. Journal of Management, Spirituality \& Religion 16: 155-77.

Duffy, Ryan D., Laura Reid, and Bryan J. Dik. 2010. Spirituality, religion, and career development: Implications for the workplace. Journal of Management, Spirituality E Religion 7: 209-21.

Dyck, Bryan. 2017. Spirituality, virtue, \& management: Theory \& evidence. In Handbook of Virtue Ethics in Business and Management. Edited by Alego J. G. Sison, Gregory Beabout and Ignacio Ferrero. Dordrecht: Springer, pp. 919-28.

Ellul, Jaques. 1976. The Ethics of Freedom. Grand Rapids: Eerdmans. 
Emerson, Tisha L. N., and Joseph A. McKinney. 2010. Importance of religious beliefs to ethical attitudes in business. Journal of Religion and Business Ethics 1: 1-15.

Emmons, Robert A. 1999. The Psychology of Ultimate Concerns: Motivation \& Spirituality in Personality. New York: The Guilford Press.

Emmons, Robert A. 2000. Is spirituality an intelligence? Motivation, cognition and the psychology of ultimate concern. The International Journal for the Psychology of Religion 10: 3-26. [CrossRef]

Ewest, Tim. 2018. The reason of faith. In Faith \& Work: Christian Perspectives, Research, and Insights into the Movement. Edited by Tim Ewest. Charlotte: Information Age Publishing, pp. 1-11.

Exline, Julie J., and David S. Bright. 2011. Spiritual and religious struggles in the workplace. Journal of Management, Spirituality E Religion 8: 123-42.

Ferguson, Duncan S. 2010. Exploring the Spirituality of the World Religions. London: Continuum.

Fernando, Mario. 2007. Spiritual Leadership in Entrepreneurial Business: A Multifaith Study. Cheltenham: Edward Elgar.

Flett, Eric G. 2005. Priests of creation, mediators of order: The human person as a cultural being in Thomas F. Torrance's theological anthropology. Scottish Journal of Theology 58: 161-83. [CrossRef]

Fornaciari, Charles J., and Kathy L. Dean. 2009. Foundations, lessons and insider tips for MSR research. Journal of Management, Spirituality E Religion 6: 301-21.

Fry, Loius W. 2003. Toward a theory of spiritual leadership. The Leadership Quarterly 14: 693-727. [CrossRef]

Fry, Loius W. 2005. Toward a theory of ethical and spiritual well-being, and corporate social responsibility through spiritual leadership. In Positive Psychology in Business Ethics and Corporate Responsibility. Edited by Robert A. Giacalone. New York: Information Age Publishing, pp. 47-83.

Fry, Louis W., and Melissa Nisiewicz. 2013. Maximizing the Triple bottom Line through Spiritual Leadership. Stanford: Stanford University Press.

Gatling, Anthony. 2015. A causal model for integrating workplace spirituality into hospitality organizational transformation. Journal of Human Resources in Hospitality $\mathcal{E}$ Tourism 14: 177-94.

Ghoshal, Sumantra. 2005. Bad management theories are destroying good management practices. Academy of Management Learning E Education 4: 75-91.

Giacalone, Robert. 2004. A transcendent business education for the 21st century. Academy of Management Learning $\mathcal{E}$ Education 3: 415-20.

Giacalone, Robert, and Carol L. Jurkiewicz. 2003. Handbook of Workplace Spirituality and Organizational Performance. Armonk: Sharpe.

Gotsis, George, and Zoi Kortezi. 2008. Philosophical foundations of workplace spirituality. Journal of Business Ethics 78: 575-600. [CrossRef]

Guillén, Manuel, Ignacio Ferrero, and W. Michael Hoffman. 2015. The neglected ethical and spiritual motivations in the workplace. Journal of Business Ethics 128: 803-16. [CrossRef]

Gull, Gregory A., and Jonathan Doh. 2004. The "transmutation" of the organization: Towards a more spiritual workplace. Journal of Management Inquiry 13: 128-39. [CrossRef]

Habets, Myk. 2009. Theosis in the Theology of Thomas Torrance. Surrey: Ashgate.

Hicks, Douglas. 2003. Religion and the Workplace: Pluralism, Spirituality, Leadership. Cambridge: Cambridge University Press.

Houghton, Jeffery D., Christopher P. Neck, and Sukumarakurup Krishnakumar. 2016. The what, why, and how of spirituality in the workplace revisited: A 14-year update and extension. Journal of Management, Spirituality $\mathcal{E}$ Religion 13: 177-205.

Howden, Julie W. 1992. Development and Psychometric Characteristics of the Spirituality Assessment Scale. Ph.D. thesis, Texas Woman's University, Denton, TX, USA.

Hunting, Amabel, and Denise Conroy. 2018. Spirituality, stewardship and consumption: New ways of living in a material world. Social Responsibility Journal 14: 255-73. [CrossRef]

Issa, Theodora, and David Pick. 2011. An interpretive mixed methods analysis of ethics, spirituality and aesthetics in the Australian service sector. Business Ethics: A European Review 20: 45-58. [CrossRef]

Jamali, Dima, and Yusuf Sdiani. 2013. Does religiosity determine affinities to CSR? Journal of Management, Spirituality E Religion 10: 309-23. 
James, Matrecia S. L., Angela K. Miles, and Terry Mullins. 2011. The interactive effects of spirituality and trait cynicism on citizenship and counterproductive work behaviors. Journal of Management, Spirituality \& Religion 8: $165-82$.

Jensen, David H. 2006. Responsive Labor. Louisville: Westminster John Knox Press.

Johnson, Avis L. 2007. Mary Parker Follett: Laying the foundations for spirituality in the workplace. International Journal of Public Administration 30: 425-39. [CrossRef]

Kale, Sudhir H. 2004. Spirituality, religion \& globalization. Journal of Macromarketing 24: 92-107.

Karakas, Fahri. 2010a. Exploring value compasses of leaders in organizations: Introducing nine spiritual anchors. Journal of Business Ethics 93: 73-92. [CrossRef]

Karakas, Fahri. 2010b. Spirituality and performance in organizations: A literature review. Journal of Business Ethics 94: 89-106. [CrossRef]

Karakas, Fahri. 2011. Positive Management Education: Creating Creative Minds, Passionate Hearts, and Kindred Spirits. Journal of Management Education 35: 198-226. [CrossRef]

Karakas, Fahri, and Emine Sarigollu. 2015. Spirals of Spirituality: A Qualitative Study Exploring Patterns of Spiritual Organizing. Academy of Management Proceedings. [CrossRef]

Keller, Tim. 2012. Every Good Endeavor: Connecting Your Work to God's Work. New York: Penguin.

Kennedy, Ellen J., and Leigh Lawton. 1998. Religiousness and business ethics. Journal of Business Ethics 17: 163-75. [CrossRef]

Kolodinsky, Robert W., Robert A. Giacalone, and Carol L. Jurkiewicz. 2008. Workplace values and outcomes: Exploring personal, organizational and interactive workplace spirituality. Journal of Business Ethics 81: 465-80. [CrossRef]

Konz, Gregory, and Franciz X. Ryan. 2000. Maintaining an organizational spirituality: No easy task. In Work $\mathcal{E}$ Spirit. Edited by Jerry Biberman and Michael D. Whitty. Scranton: University of Scranton Press, pp. 233-48.

Krishnakumar, Sukumarakurup, and Christopher P. Neck. 2002. The "what", "why" and "how" of spirituality in the workplace. Journal of Managerial Psychology 17: 153-64. [CrossRef]

Kutcher, Eugene J., Jennifer D. Bragger, Ofelia Rodriguez-Srednicki, and Jamie L. Masco. 2010. The role of religiosity in stress, job attitudes and organizational citizenship behavior. Journal of Business Ethics 95: 319-37. [CrossRef]

Larive, Armand. 2004. After Sunday: A Theology of Work. New York: Continuum.

Lee, Seonjeong, Kathi J. Lovelace, and Charles C. Manz. 2014. Serving with spirit: An integrative model of workplace spirituality within service organizations. Journal of Management, Spirituality $\mathcal{E}$ Religion 11: 45-64.

Lips-Wiersma, Marjo. 2002. Analysing the career concerns of spiritually oriented people: Lessons for contemporary organizations. Career Development International 7: 385-97. [CrossRef]

Lips-Wiersma, Marjo, and Venkataraman Nilakant. 2008. Practical compassion: Toward a critical spiritual foundation for corporate responsibility. In Spirituality in Business: Theory, Practice, and Future Directions. Edited by Jerry Biberman and Len Tischler. New York: Palgrave Macmillan, pp. 51-72.

Longnecker, Justin G., Joseph A. McKinney, and Carlos W. Moore. 2004. Religious intensity, evangelical Christianity, and business ethics: An empirical study. Journal of Business Ethics 55: 373-86. [CrossRef]

Lund Dean, Kathy, Scott Safranski, and E. Scott Lee. 2014. Religious accommodation in the workplace: Understanding religious identity threat and workplace behaviors in legal disputes. Employee Responsibilities and Rights Journal 26: 75-94. [CrossRef]

Lynn, Monty L., Michael J. Naughton, and Steve VanderVeen. 2011. Connecting religion and work: Patterns and influences of work-faith integration. Human Relations 64: 675-701. [CrossRef]

Markow, Frank, and Karin Klenke. 2005. The effects of personal meaning and calling on organizational committment: An empirical investigation of spiritual leadership. The International Journal of Organizational Analysis 13: 8-27. [CrossRef]

Marler, Penny Long, and C. Kirk Hadaway. 2002. "Being religious" or "being spiritual" in America: A zero sum proposition? Journal for the Scientific Study of Religion 41: 289-300. [CrossRef]

Marques, Joan. 2010. Spiritual considerations for managers: What matters most to workforce members in challenging times. Journal of Business Ethics 97: 381-90. [CrossRef]

Marschke, Eleanor, Robert Preziosi, and William J. Harrington. 2011. How sales personnel view the relationship between job satisfaction and spirituality in the workplace. Journal of Organization Culture, Communications and Conflict 15: 71-110. 
Marshall, P. 1980. Labour of Love: Essays on Work. Toronto: Wedge Publishing Foundation.

Mazereeuw-van der Duijn Schouten, Corrie, Johan Graafland, and Muel Kaptein. 2014. Religiosity, CSR attitudes, and CSR behavior: An empirical study of executives' religiosity and CSR. Journal of Business Ethics 123: 437-59. [CrossRef]

McCarty, William B. 2007. Prayer in the workplace: Risks and strategies to manage them. Business Renaissance Quarterly 2: 97-105.

McGhee, Peter K. 2015. The Role of Spirituality in Ethical Decision-Making and Behavior and the Benefits to Organizations: A Critical Realist Analysis. Ph.D. thesis, University of Auckland, Auckland, New Zealand.

McGhee, Peter K., and Myk Habets. 2018. Priests of creation, mediators of order: Taking God to work. In Faith and Work: Christian Perspectives, Research and Insights into the Movement. Edited by T. Ewest. Charlotte: IAP, pp. 77-96.

Meeks, Douglas. 1989. God the Economist. Minneapolis: Fortress Press.

Meskelis, Simone, and J. Lee Whittington. 2018. Work as worship: Bringing meaning to work as integrated faith. In Faith \& Work: Christian Perspectives, Research, and Insights into the Movement. Edited by T. Ewest. Cahrlotte: IAP, pp. 57-76.

Miller, David W. 2007. God at Work: The History and Promise of the Faith at Work Movement. New York: Oxford University Press.

Miller, David W., and Tim Ewest. 2013. The present state of workplace spirituality: A literature review considering context, theory, and measurement/assessment. Journal of Religious $\mathcal{E}$ Theological Information 12: 29-54.

Miller, David W., and Tim Ewest. 2015. A new framework for analyzing organizational workplace religion and spirituality. Journal of Management, Spirituality E Religion 12: 305-28.

Miller, David W., and Tim Ewest. 2018. Spirituality at the Workplace. In Encyclopedia of Business and Professional Ethics. Edited by Deborah C. Poff and Alex C. Michalos. Cham: Springer International Publishing, pp. 1-5.

Miller, David W., Faith W. Ngunjiri, and James D. LoRusso. 2017. Human resources perceptions of corporate chaplains: Enhancing positive organizational culture. Journal of Management, Spirituality E Religion 14: 196-215.

Milliman, John, Anthony Gatling, and Jill C. Bradley-Geist. 2017. The implications of workplace spirituality for person-environment fit theory. Psychology of Religion and Spirituality 9: 1-12. [CrossRef]

Mirvis, Philip H. 1997. "Soul work” in organizations. Organization Science 8: 193-206. [CrossRef]

Mitroff, Ian I. 2003. Do not promote religion under the guise of spirituality. Organization 10: 375-82. [CrossRef]

Mitroff, Ian I., and Elizabeth A. Denton. 1999. A Spiritual Audit of Corporate America: A Hard Look at Spirituality, Religion and Values in the Workplace. San Francisco: Jossey-Bass.

Moe-Lobeda, Cynthia D. 2002. Healing a Broken World: Globilization E God. Minneapolis: Fortress Press.

Moltmann, Jurgen. 1997. The Source of Life. Minneapolis: Augsburg Press.

Moore, Geoff. 2008. Re-imagining the morality of management: A modern virtue ethics approach. Business Ethics Quarterly 18: 483-511. [CrossRef]

Neal, Julie, B. Lichtenstein, and David Banner. 1999. Spiritual perspectives on individual organizational and societal transformation. Journal of Organizational Change Management 12: 175-85. [CrossRef]

Paul, Pope John, II. 1981. Laborem Exercens. Available online: http://w2.vatican.va/content/john-paul-ii/en/ encyclicals/documents/hf_jp-ii_enc_14091981_laborem-exercens.html (accessed on 4 July 2019).

Pawar, Badrinarayan S. 2009. Workplace spirituality facilitation: A comprehensive model. Journal of Business Ethics 90: 375-86. [CrossRef]

Pfeffer, Jeffrey. 2003. Business and the spirit: Management practices that sustain values. In The Handbook of Workplace Spirituality and Organizational Performance. Edited by Robert A. Giacalone and Carol L. Jurkiewicz. Armonk: M.E. Sharpe, pp. 29-45.

Pradhan, Rabindra K., and Lalatendu K. Jena. 2015. Workplace spirituality and employee performance: Mediating role of organization citizenship behavior. Journal of Contemporary Psychological Research 2: 40.

Pratt, Michael G., and Blake E. Ashforth. 2003. Fostering meaningfulness in working and at work. In Positive Organizational Scholarship: Foundations of a New Discipline. Edited by Kim S. Cameron, Jane E. Dutton and Robert E. Quinn. San Francisco: Berrett-Koehler Publishers, pp. 309-27.

Rozuel, Cécile, and Nada Kakabadse. 2010. Ethics, spirituality and self: Managerial perspectives and leadership implications. Business Ethics: A European Review 19: 423-36. [CrossRef] 
Sass, James S. 2000. Characterizing organizational spirituality: An organizational communication culture approach. Communication Studies 5: 195-217. [CrossRef]

Sayers, Dorothy. 2011. Why Work? McLean: The Trinity Forum. First published 1949.

Schneiders, Sandra M. 2003. Religion vs. spirituality: A contemporary conundrum. Spiritus 3: 163-85. [CrossRef] Sheep, Matthew L. 2006. Nurturing the whole person: The ethics of workplace spirituality in a society of organizations. Journal of Business Ethics 66: 357-75. [CrossRef]

Singhapakdi, Anusorn, Janet K. Marta, Kumar C. Rallapalli, and C. P. Rao. 2000. Toward an understanding of religiousness and marketing ethics: An empirical study. Journal of Business Ethics 27: 305-19. [CrossRef]

Snyder, Charles Richard, Shane J. Lopez, and Jennifer T. Pedrotti. 2011. Positive Psychology: The Scientific E Practical Explorations of Human Strengths. Los Angeles: Sage.

Staniloae, Dumitru. 2000. The Experience of God: Orthodox Dogmatic Theology: The World, Creation, and Deification. Brookline: Holy Cross Orthodox Press.

Stevens, R. Paul. 1999. The Other Six Days: Vocation, Work, and Ministry in Biblical Perspective. Grand Rapids: Eerdmans. Sweet, Leonard. 1999. Soultsunami: Sink or Swim in New Millennium Culture. Grand Rapids: Zondervan.

Tanner, Kathryn. 2005. Economy of Grace. Minneapolis: Fortress Press.

Tejeda, Manuel J. 2015. Exploring the supportive effects of spiritual well-being on job satisfaction given adverse work conditions. Journal of Business Ethics 131: 173-81. [CrossRef]

Tongo, Constantine I. 2016. Transcendent work motivation: Biblical and secular ontologies. Journal of Management, Spirituality \& Religion 13: 117-42.

Torrance, Thomas F. 1965. Theology in Reconstruction. Scotland: SCM Press.

Torrance, Thomas F. 1980. The Ground and Grammer of Theology. Edinburgh: T \& T Clark.

Torrance, Thomas F. 1982. Reality and Evangelical Theology. Philadelphia: Westminster.

Torrance, Thomas F. 1992. The Mediation of Christ. Edinburgh: T \& T Clark.

Torrance, Thomas F. 1996. The Christian Doctrine of God: One Being Three Persons. Edinburgh: Scotland, T \& T Clark.

Van Buren, Harry J., III. 1995. Work and religious faith: How people of faith relate to their employers. International Journal of Value-Based Management 8: 279-88. [CrossRef]

Vandenberghe, Christian. 2011. Workplace spirituality and organizational commitment: An integrative model. Journal of Management, Spirituality \& Religion 8: 211-32.

Verquer, Michelle L., Terry A. Beehr, and Stephen H. Wagner. 2003. A meta-analysis of the relations between person-organization fit and work attitudes. Journal of Vocational Behavior 63: 473-89. [CrossRef]

Volf, Miroslav. 2001. Work in the Spirit: Toward a Theology of Work. London: Oxford University Press.

Walker, Allan G. 2013. The relationship between the integration of faith and work with life and job outcomes. Journal of Business Ethics 112: 453-61. [CrossRef]

Weaver, Gary R. 2006. Virtue in organizations: Moral indentity as a foundation for moral agency. Organization Studies 27: 341-68. [CrossRef]

Wink, Paul, and Michele Dillion. 2002. Spiritual development across the adult life course: Findings from a longitudinal study. Journal of Adult Development 9: 79-94. [CrossRef]

Yu, Kang Y. T. 2013. A motivational model of person-environment fit: Psychological motives as drivers of change. In Organizational Fit: Key Issues and New Directions. Edited by Amy Kristof-Brown and Jon Billsberry. West Sussex: Wiley-Blackwell, pp. 21-49.

Zapf, Lucas, and Peter Seele. 2018. As the birds to flying, so is man born unto work. In Faith \& Work: Christian Perspectives, Research $\mathcal{E}$ Insights into the Movment. Edited by Tim Ewest. Charlotte: IAP, pp. 97-114.

Zellars, Kelly L., and Pamela L. Perrewe. 2003. The role of spirituality in occupational stress and well-being. In Handbook of Workplace Spirituality \& Organizational Performance. Edited by Robert A. Giacalone and Carol L. Jurkiewicz. Armonk: M.E. Sharpe, pp. 300-13.

Zinnbauer, Brian J., Kenneth I. Pargament, and Allie B. Scott. 1999. The emerging meanings of religiousness and spirituality: Problems and prospects. Journal of Personality 67: 889-919. [CrossRef]

Zsolnai, Laszlo. 2004. Spirituality \& management. In Spirituality and Ethics in Management. Edited by Laszlo Zsolnai. Dordrecht: Kluwer Academic Publishers, pp. 3-12.

(C) 2019 by the author. Licensee MDPI, Basel, Switzerland. This article is an open access article distributed under the terms and conditions of the Creative Commons Attribution (CC BY) license (http://creativecommons.org/licenses/by/4.0/). 